\title{
Effect of feeding crude or treated tung meal (Aleurites fordii) in the diet of Rhamdia quelen on growth, digestive enzymes and biochemical parameters
}

\section{Efeitos da alimentação de farelo de tungue (Aleurites fordii) bruto ou tratado na dieta de Rhamdia quelen sobre o crescimento, enzimas digestivas e parâmetros bioquímicos}

\author{
Alexandra Pretto $^{1 *}$ (D) , Leila Picolli da Silva² (D) , Viviani Corrêia ${ }^{1}$ (D) , Suziane Ghedini \\ Martinelli ${ }^{3}$ ii \\ 1 Universidade Federal do Pampa, Uruguaiana, RS, Brazil. \\ ${ }^{2}$ Universidade Federal de Santa Maria, Santa Maria, RS, Brazil. \\ ${ }^{3}$ Instituto Federal de Educação, Ciência e Tecnologia do Amazonas, Lábrea, AM, Brazil. \\ ${ }^{*}$ Correspondent - ale.pretto@yahoo.com.br
}

Seção: Recursos Pesqueiros e
Engenharia de Pesca
Received
April 6, 2017.
Accepted
October 22, 2019.
Published
February 5, 2020.
www.revistas.ufg.br/vet
Como citar - disponível no site,
na página do artigo.

\section{Abstract}

This study evaluated the addition of tung (Aleurites fordii) meal to the feed of Rhamdia quelen, as an alternative to animal protein sources. Silver catfish juveniles were fed different diets which included crude tung meal, chemically treated tung meal and a control without tung meal. The chemical treatment was based on the sequential application of acid and alcohol solutions and reduced the phytic acid from 1.63 to $0.61 \%$ and condensed tannin content from 0.025 to $0.018 \%$. The nutritional response of fish to these ingredients was evaluated over nine weeks, based on growth performance, digestive enzyme activity and biochemical responses. After nine weeks, the diet containing crude tung meal caused reduced growth (weight: $-57.9 \%$; total length: $-21.09 \%$; specific growth rate: $-99.74 \%)$. This diet also reduced acid protease and lipase activities, decreased concentrations of glucose, cholesterol and triglycerides in plasma and decreased liver glycogen and glucose concentrations. However, after nine weeks, fish fed with treated tung meal showed higher growth (weight, total length and specific growth rate similar to control) and reduced metabolic changes, possibly due to the removal of antinutrients and toxic substances. At the $32 \%$ level of inclusion, the chemically treated tung meal can be considered an alternative protein source for silver catfish.

Keywords: Agro by-products. Alternative protein. Biochemical parameters. Growth response. Silver catfish.

\section{Resumo}

Este estudo avaliou a adição de farelo de tungue (Aleurites fordii) na dieta de Rhamdia quelen, como uma alternativa à fontes de proteína animal. Juvenis de jundiá foram alimentados com diferentes dietas incluídas de farelo de tungue bruto, farelo quimicamente tratado e uma dieta controle sem farelo de tungue. O tratamento químico foi baseado na aplicação sequencial de soluções ácida e alcoólica e reduziu o conteúdo de ácido fítico de $1,63 \%$ para $0,61 \%$ e o conteúdo de taninos condensados de $0,025 \%$ para $0,018 \%$. A resposta nutricional dos peixes à 
estes ingredientes foi avaliada ao longo de nove semanas, baseado no crescimento, atividade de enzimas digestivas e respostas bioquímicas. Após nove semanas, a dieta contendo farelo de tungue bruto causou reduzido crescimento (peso: $-57,9 \%$; comprimento total: $-21,09 \%$; taxa de crescimento específico: -99,74\%). Esta dieta também reduziu a atividade de protease ácida e lipase, reduziu concentrações de glicose, colesterol e triglicerídeos no plasma e concentrações de glicogênio e glicose no fígado. No entanto, após nove semanas, os peixes alimentados com farelo de tungue tratado mostraram maior crescimento (peso, comprimento total e taxa de crescimento específico igual ao controle) e poucas alterações metabólicas, possivelmente devido a remoção de antinutrientes e substâncias tóxicas. Ao nível de $32 \%$ de inclusão, o farelo de tungue quimicamente tratado pode ser considerado uma fonte de proteína alternativa para o jundiá.

Palavras-chave: Co-produtos agroindustriais. Proteína alternativa. Parâmetros bioquímicos. Resposta de crescimento. Jundiá.

\section{Introduction}

Among the most prominent oilseeds used for biofuel production in Brazil are soybean, sunflower, palm, castor and canola. A promising new agricultural product is tung (Aleurites fordii), a perennial plant native to China whose fruits contain a high oil content (47-63\%). The cultivation is concentrated in the South of Brazil, where it reaches about $600 \mathrm{ha}^{(1)}$. The average fruit yield reaches 9,000 kg/ha, and the extracted oil is currently used in the production of paints and resins but could potentially be used as an alternative oil in the biodiesel industry ${ }^{(2)}$. However, the production of biofuels, like all industrial activity, generates large amounts shells, meals and pies (obtained from the mechanical pressing of oil seeds). A carefully studied and excellent alternative use for these by-products is in fish farming, since the commercial aquafeed companies are seeking alternative ingredients (considering both economic and environmental aspects) to replace the animal protein sources (fish and meat meals) that are traditionally used, as these have high costs and high heterogeneity in their nutritional composition ${ }^{(3)}$.

In general, plant protein sources present antinutrients (e.g., tannins, phytates, polyphenols and mucilage) that may adversely affect digestive physiology and nutrient bioavailability ${ }^{(4)}$. Information about the undesirable compounds in tung meal are limited. One study suggested that the toxicity of the meal is the result of the presence of saponin and allergenic albumin ${ }^{(5)}$. Moreover, fibres, phytic acid and tannins are antinutrients also found in tung meal.

The application of specific treatments (chemical, thermal or enzymatic) can improve the nutritional value and digestibility of these byproducts. Thermolabile molecules, such as protease inhibitors, lectins, antivitamins and goitrogens, can be destroyed with dry or moist heat, whereas thermostable molecules including saponins, non-starch polysaccharides, antigenic proteins and phenolic compounds can be extracted with water, organic solvents or acid solutions ${ }^{(4,6)}$. For this study, tung meal was sequentially washed with acid and alcoholic solutions to remove the antinutrients. When applied to 
Hungarian carp (Cyprinus carpio) feeding, treated tung meal caused better performance in the fish in relation to the crude meal(7).

Thus, the aim of this study was to investigate the use of crude tung meal (without treatment) or chemically treated tung meal (reduced in antinutrients) as a partial substitute for animal protein in the diet of Rhamdia quelen (silver catfish) on growth, digestive enzyme activity and metabolic parameters in juveniles.

\section{Materials and methods}

All procedures involving animals were performed in accordance with the standards approved by the Ethics Committee for Animal Welfare at the Federal University of Santa Maria, Brazil, by protocol number 026/2011.

The experiment was conducted in the fish farming laboratory of the Federal University of Santa Maria, from July to September 2011. In this study, 153 silver catfish juveniles with initial measures of $22 \pm 0.46 \mathrm{~g}$ and $13 \pm 0.10 \mathrm{~cm}$ were utilised. We placed $17 \mathrm{fish}$ into each of the nine experimental units, tanks with $125 \mathrm{~L}$ water capacity, arranged in a water recirculation system with two biological filters containing crushed stone and two electric heaters $(1,000 \mathrm{~W})$ to control the water temperature.

Tung meal was included in the diets in either its crude or chemically treated form. For the crude meal, the product was obtained after the mechanical and chemical removal of oil from the seeds. The chemically treated tung meal had reduced antinutritional factors, which was achieved by the sequential application of an acid solution with $\mathrm{pH}$ 1.0 made with concentrated sulphuric acid (weight:volume ratio 1:10) and an alcohol solution using $92.8 \%$ ethanol (weight:volume ratio 1:7.5) to the crude meal. The meal was stirred on a shaker at $240 \mathrm{rpm}$ for one hour with each solution. The resulting mixture was filtered through two sieves $(25$ and $100 \mu \mathrm{m})$ to separate the liquid portion from the solid. Prior to the second filtration, the $\mathrm{pH}$ of the mixture was raised to 7.0 with sodium hydroxide solution $1 \mathrm{~N}$. Proteins dissolved in the liquid medium were recovered by concentration. This was achieved by changing the $\mathrm{pH}$ of the solution, firstly raising the $\mathrm{pH}$ to 9.0 with $\mathrm{NaOH} 1 \mathrm{~N}$ and then reducing it to $\mathrm{pH} 4.5$ with hydrochloric acid $1 \mathrm{~N}$, using a digital $\mathrm{pH}$ meter to monitor the pH (MPA 210-P, Servilab, Brazil). This protein concentration methodology is based on the isoelectric point of amino acids. The solid fraction of the meal and the concentrated protein fraction were dried in an forced air circulation oven at $60^{\circ} \mathrm{C}$ for 24 hours.

Total phenolic compounds and tannins total and condensed were analysed according to Makkar ${ }^{(8)}$. Acetone was used for the extraction of these fractions. After the acetone extraction the total tannins were extracted with polyvinylpolypyrrolidone (PVPP). The determinations were performed using a colorimetric assay using the Folin-Ciocalteu reagent and tannic acid as the standard. For the quantification of condensed tannins, solutions of butanol-hydrochloric acid and ammonium iron sulphate in hydrochloric acid were added and heated, after which the absorbance was determined at $550 \mathrm{~nm}$. The concentration of hydrolysable tannins was obtained by calculating the difference 
between the total tannin and condensed tannin concentrations. Phytic acid concentration was determined according to Latta \& Eskin ${ }^{(9)}$ after extraction with a hydrochloric acid solution. A column containing an anion exchange resin (AG1-X4, Bio-Rad) was used, and the phytic acid retained on the resin was eluted in a sodium chloride solution, and then collected and measured colorimetrically by spectrophotometry to $500 \mathrm{~nm}$. $90 \%$ purity phytic acid salt (Sigma) was used as the standard.

The in vitro digestibility of the protein assay was performed according Dias et al..(10). The method is based on the digestion of the sample by pepsin (1:10.000, Nuclear) and pancreatin (Sigma) enzymes. The digestibility was determined from the relationship between the total nitrogen in the sample, digested nitrogen, nitrogen produced by autodigestion by the enzymes and the soluble nitrogen originally contained within the sample.

The experimental design was completely randomised with three treatments and three replicates, including the crude tung diet (CTD), the treated tung diet (TTD) and a control (CON) diet, in which the basic protein was meat and bone meal and fish meal. The ingredients used in these formulations have been previously analysed for dry matter, ash, crude protein ${ }^{(11)}$, fat $^{(12)}$, neutral detergent fibre ${ }^{(13)}$, calcium and phosphorus ${ }^{(14)}$ and amino acids by High Performance Liquid Chromatography (Table 1).

Table 1. Proximate composition (\%) of the ingredients used in the experimental diets

\begin{tabular}{lcccccc}
\hline \multirow{2}{*}{ Nutrients } & \multicolumn{5}{c}{ Ingredients } \\
\cline { 2 - 7 } & FM & MBM & CT & TT & WF & CG \\
\hline Dry matter & 92.63 & 95.05 & 89.01 & 96.92 & 88.30 & 89.31 \\
Crude protein & 56.41 & 53.40 & 24.90 & 26.69 & 15.37 & 7.33 \\
Fat & 7.09 & 14.68 & 2.98 & 1.08 & 3.59 & 4.89 \\
Ash & 28.64 & 24.84 & 6.25 & 6.82 & 4.07 & 1.53 \\
NDF & ND & ND & 46.54 & 56.78 & 33.06 & 15.58 \\
Carbohydrate & 0.49 & 2.13 & 8.34 & 5.55 & 32.21 & 59.98 \\
Calcium & 5.09 & 3.46 & 0.34 & 0.25 & 0.12 & 0.04 \\
Total phosphorus & 2.87 & 1.97 & 2.61 & 1.23 & 0.95 & 0.18 \\
Lysine & 2.99 & 3.00 & 0.97 & 1.05 & 0.54 & 0.22 \\
Methionine & 0.99 & 1.25 & 0.61 & 0.56 & 0.22 & 0.16 \\
Arginine & 2.97 & 3.54 & 2.34 & 2.50 & 0.96 & 0.36 \\
Histidine & 1.00 & 1.16 & 0.25 & 0.26 & 0.34 & 0.20 \\
Isoleucine & 1.91 & 1.63 & 0.86 & 0.94 & 0.46 & 0.23 \\
Leucine & 3.76 & 3.16 & 1.50 & 1.66 & 0.86 & 0.98 \\
Phenylalanine & 2.08 & 3.46 & 1.6 & 1.65 & 0.58 & 0.34 \\
Threonine & 2.04 & 1.75 & 0.72 & 0.79 & 0.41 & 0.23 \\
Tryptophan & 0.39 & 0.40 & ND & ND & 0.23 & 0.05 \\
Valine & 2.54 & 2.22 & 1.72 & 1.95 & 0.64 & 0.35 \\
\hline
\end{tabular}

Medium values $(n=3)$. ' $\mathrm{FM}=$ Fish meal; MBM=Meat bone meal; $C T$; Crude tung meal; $T T=$ Treated tung meal; $W F=$ Wheat flour; $C G=$ Corn grain. ${ }^{2} \mathrm{NDF}=$ neutral detergent fibre. $N D=$ not determined. 
The tung meal was substituted for $20 \%$ of the animal protein (meat and bone meal and fish meal) in diets containing approximately 34\% of crude protein and 3,100 Kcal/ $\mathrm{Kg}$ of digestible energy based on the study of Pretto et al. ${ }^{(7)}$ (Table 2). Where necessary, methionine and lysine were included in the diet in order to meet the nutritional requirement of the species ${ }^{(15)}$. The diets were analysed for dry matter, ash, crude protein, fat and neutral detergent fibre according the methodologies mentioned above.

Table 2. Formulation ( $/ / \mathrm{Kg}$ ) and proximate composition (\%) of the experimental diets

\begin{tabular}{|c|c|c|c|}
\hline \multirow{2}{*}{ Ingredients } & \multicolumn{3}{|c|}{ Treatments $^{1}$} \\
\hline & CON & CTD & TTD \\
\hline Fish meal & 125.0 & 98.4 & 97.3 \\
\hline Meat and bone meal & 435 & 350 & 348 \\
\hline Crude tung meal & - & 324.5 & - \\
\hline Treated tung meal & - & - & 324.5 \\
\hline Wheat flour & 129.5 & 38 & 32 \\
\hline Corn grain & 162.4 & 59 & 29.5 \\
\hline Corn starch & 20.4 & 38 & 72.1 \\
\hline Soybean oil & 40 & 61.8 & 66.2 \\
\hline Salt & 5 & 5 & 5 \\
\hline Vitamin/mineral mixture ${ }^{2}$ & 20 & 20 & 20 \\
\hline Methionine & 5.4 & 5 & 5.3 \\
\hline Calcium carbonate & - & 0.3 & 0.1 \\
\hline Inert (sand) & 57.3 & - & - \\
\hline Crude protein ${ }^{3}$ & 33.91 & 33.84 & 33.97 \\
\hline Fat $^{3}$ & 12.45 & 13.38 & 13.00 \\
\hline $\mathrm{Ash}^{3}$ & 15.14 & 13.79 & 13.82 \\
\hline Neutral detergent fibre ${ }^{3}$ & 6.62 & 17.28 & 19.94 \\
\hline Carbohydrates ${ }^{4}$ & 14.16 & 8.26 & 5.39 \\
\hline Digestible energy ${ }^{5}$ (Kcal/Kg) & 3070 & 3048 & 3063 \\
\hline Calcium 6 & 2.26 & 3.07 & 2.30 \\
\hline Total phosphorus ${ }^{6}$ & 1.37 & 1.87 & 1.40 \\
\hline Ca:P ratio & 1.66 & 1.64 & 1.64 \\
\hline Lysine $^{6}$ & 1.78 & 1.69 & 1.70 \\
\hline Methionine ${ }^{6}$ & 1.25 & 1.25 & 1.26 \\
\hline Arginine $^{6}$ & 2.09 & 2.35 & 2.37 \\
\hline Histidine $^{6}$ & 0.71 & 0.61 & 0.60 \\
\hline Isoleucine ${ }^{6}$ & 1.04 & 1.07 & 1.08 \\
\hline Leucine $^{6}$ & 2.11 & 2.05 & 2.06 \\
\hline Phenylalanine ${ }^{6}$ & 1.89 & 1.98 & 1.97 \\
\hline Threonine $^{6}$ & 1.11 & 1.14 & 1.08 \\
\hline Tryptophan 6 & 0.26 & 0.20 & 0.18 \\
\hline Valine $^{6}$ & 1.42 & 1.54 & 1.68 \\
\hline
\end{tabular}

'CON=control diet, with protein base consisting of animal meal; $C T D=$ inclusion of crude tung meal in the diet; TTD = inclusion of treated tung meal in the diet. ${ }^{2} \mathrm{Vitamin} / \mathrm{mineral}$ (kg product): Folic acid: $300 \mathrm{mg}$; Choline: $100 \mathrm{~g}$; Inositol: 10g; Niacin: $9000 \mathrm{mg}$; Pantothenic acid: $3000 \mathrm{mg}$; Biotin: 0.1mg; Vit.A: $1000000 \mathrm{Ul}$; Vit. B1: $1500 \mathrm{mg}$; Vit. B2: 1500mg; Vit. B6: $150 \mathrm{mg}$; Vit. B12: $2000 \mathrm{mg}$; Vit. C: $15 \mathrm{~g}$; Vit. D3: $240000 \mathrm{Ul}$; Vit. E: $10000 \mathrm{mg}$; Vit. K3: $400 \mathrm{mg}$; Copper: $1000 \mathrm{mg}$; Iron: $6000 \mathrm{mg}$; lodine: $45 \mathrm{mg}$; Manganese: $8000 \mathrm{mg}$; Selenium: $60 \mathrm{mg}$; Zinc: $14 \mathrm{~g}$. ${ }^{3}$ Composition analysed; ${ }^{4}$ Carbohydrate calculated: 100 -(crude protein $+a s h+$ fat+neutral detergent fiber+moisture). ${ }^{5}$ Calculated from the formula: (Protein $\star 5,64 * 0,83)+($ fat $* 9,44 * 0,88)+($ Carbohydrate*4,11*0,65) $) * 10(16) .{ }^{6}$ Calculated based on the ingredients analysis. 
The dry ingredients were ground, mixed and combined with soybean oil and water. Water represented $50 \%$ of the dry weight of the ingredients. Mixtures were pelleted in a meat grinder and dried in a forced air circulation oven at $50^{\circ} \mathrm{C}$ for 24 hours. The pellets were packed in plastic bags and kept at $-18^{\circ} \mathrm{C}$ until used. The experimental diets were fed to the fish for nine weeks. The diet was provided daily in addition to a fixed percentage of biomass per experimental unit. This percentage had previously been used and had been adjusted for each biometric in order to prevent feed leftovers. The percentage, which ranged from 2-3\% of the biomass of each tank throughout the experiment, was divided into three meals 9:00 A.M., 1:00 P.M. and 5:00 P.M. The tanks were cleaned by siphoning out faeces and food residues twice daily at 8:00 A.M. and 3:30 P.M., with renewal of approximately $10 \%$ of the water from each tank.

The water quality of the culture system was monitored daily for temperature, and an average value of $22.09 \pm 0.82^{\circ} \mathrm{C}$ was found. The dissolved oxygen was monitored weekly using a handheld dissolved oxygen instrument (YSI® 550A) and $6.02 \pm 0.71 \mathrm{mg} / \mathrm{L}$ in the breeding water was found. Other parameters were determined as $\mathrm{pH}$, using a $\mathrm{pH}$ meter (MPA 210-P, Servilab), total ammonia ${ }^{(17)}$, nitrite, alkalinity and hardness ${ }^{(18)}$. The values found were, respectively, $6.82 \pm 0.14$ units, $0.11 \pm 0.09 \mathrm{mg} / \mathrm{L}, 0.05 \pm 0.01 \mathrm{mg} / \mathrm{L}, 20.78 \pm$ $5.32 \mathrm{mg} / \mathrm{L} \mathrm{CaCO}_{3}$ and $43.56 \pm 10.28 \mathrm{mg} / \mathrm{L} \mathrm{CaCO}_{3}$. All parameters remained within the range suitable for silver catfish ${ }^{(19)}$.

Fish were measured and weighed every three weeks to monitor growth. Before the biometry, the fish were fasted for 18 hours and were anesthetised with eugenol $(20 \mu \mathrm{L}$ pure extract/ $/ L$ water) ${ }^{(20)}$. The final live weight $(L W)$, total length $(T L)$, specific growth rate (SGR=[In (final weight) - In (initial weight)/period)]); feed conversion rate (FCR = g dry feed given/g live weight gain) and survival ( $\mathrm{S}=$ live animals in the period/initial number of animals in the tank) were determined.

After nine weeks of feeding, two fish per tank and six for each treatment were captured for blood and tissue collection. Firstly, blood was collected from the caudal vein using heparinised syringes, and then the fish were killed by spinal cord excision behind the operculum to remove the digestive tract and liver. These organs were quickly placed on ice and frozen at $-20^{\circ} \mathrm{C}$ for digestive enzyme and biochemical parameter analysis. Plasma aliquots were separated for the determination of plasma metabolic parameters after the centrifugation of the blood at room temperature for 10 minutes at 1,200 g.

The digestive tract was separated into the stomach and total intestine. Each section was homogenised (tissue:buffer ratio 1:20) in a homogenisation buffer composed of $0.02 \mathrm{M}$ Tris, $0.01 \mathrm{M}$ phosphate, $\mathrm{pH} 7.5$ in $50 \%$ [v/v] of glycerol. The homogenates were centrifuged at 1,200 g for 10 minutes, and the supernatants were used as the enzyme source. The acid protease activity was measured in the stomach homogenate using a nonspecific substrate, the casein, according to Hidalgo et al.(21). Trypsin, chymotrypsin and a-amylase and lipase activities were determined in the intestine homogenate. Trypsin activity was assayed with a-p-toluenosulfonyl-L-arginine methyl ester hydrochloride (TAME), and chymotrypsin activity was assayed with benzoyl tyrosine ethyl ester (BTEE) using the protocol described by Hummel (22). The experimental protocol used to determine the a-amylase activity has been described by Hidalgo et al.(21). The starch hydrolysed by the enzyme was determined as described by Park \& Johnson ${ }^{(23)}$. Lipase 
activity was measured according to Gawlicka et al.(24) using p-nitrophenyl myristate as the substrate. All samples were assayed in duplicate and the readings were normalised using blank solutions. The protein content of the crude extracts was determined by the Bradford(25) method using bovine serum albumin as the standard.

To determine the hepatic biochemical parameters, the liver was divided into $50 \mathrm{mg}$ samples. Liver glycogen levels were determined according to Bidinotto et al(26) $^{(26 t e r}$ the addition of $\mathrm{KOH}$ and ethanol for the hydrolysis and precipitation of glycogen. For the protein analysis, the tissue was heated at $100^{\circ} \mathrm{C}$ with $\mathrm{KOH}$ and centrifuged at 1,000 $\mathrm{g}$ for 10 minutes, and the supernatant was used to estimate the total protein level according to the Bradford ${ }^{(25)}$ method. For the soluble sugar analysis( ${ }^{(27)}$, tissue samples were homogenized by adding 10\% TCA and centrifuged at 1,000 g for 10 minutes for protein flocculation. To measure the concentration of hepatic transaminases were used colorimetric kits (Doles, Goiás, Brazil). Liver samples were mechanically disrupted with the addition of phosphate buffer $20 \mathrm{mM}$ and $\mathrm{pH} 7.5$ and were centrifuged at 1,000 g for 10 minutes. For the analysis of plasmatic parameters, such as glucose, total protein, triglycerides and cholesterol, colorimetric kits also were used (Doles, Goiás, Brazil).

At the beginning of the experiment, a sample of fish of ten animals were collected for body composition analysis and, at the end of the trial period, two fish per tank, which represents six per treatment, were sampled. Prior to analysis, the samples were ground using a food processor. The moisture concentration was determined by heating at $60^{\circ} \mathrm{C}$ overnight then at $105 \pm 2{ }^{\circ} \mathrm{C}$ for 24 hours; ash was determined by heating at $550^{\circ} \mathrm{C}$ for 6 hours; crude protein was quantified by nitrogen determination using the microKjeldahl method $(\mathrm{N} \times 6.25)$ and fat, were determined by the methods described above.

The data were tested for normality through the Shapiro-Wilk test and then subjected to one-way ANOVA, including the multiple comparisons between the tung meal treatments and the control group using Dunnett's test. The F-test was used to compare the means between the treatments with either the crude or treated tung meal in the fish feeding trial. The data were expressed as the mean \pm standard error of the mean $(p<0.05)$. Statistical analysis were performed using the Statistical Analysis System SAS ${ }^{\circledR}$ software version 8.2 .

\section{Results}

The treated tung meal had $64.8 \%$ less phytic acid and $28 \%$ less condensed tannin compared to crude tung meal. Phenolic compounds and total and hydrolysable tannins were unchanged compared to the crude meal. The in vitro digestibility of protein increased by $13.5 \%$ after chemical treatment of the tung meal (Table 3). The digestibility of the meals was performed compared to the digestibility of casein, which has a digestibility of $92.32 \%$.

The inclusion of crude tung meal in silver catfish feed resulted in a significant reduction in growth after three, six and nine weeks. Lower live weight (LW), total length (TL) and specific growth rates (SGR) were observed in these animals compared with those fed with diets containing treated tung meal and the control diet (Table 4). Until the sixth 
week of feeding, the animals that received the treated tung meal in the diet presented reduced growth compared to the animals fed the control diet, but by end of the nine week experiment, the weight, total length and specific growth rate had not differed statistically. The feed conversion rate did not show a significant difference in the fish fed the treated tung meal diet in relation to the control diet from the sixth feeding week. It was not possible to calculate the feed conversion rate for fish fed the crude tung meal diet due extremely low growth and mortality of the animals. The survival rate of animals fed with the crude tung meal diet was $68 \%$, whereas survival was $100 \%$ with the treated tung meal diet.

Table 3. Antinutrients analysed in crude tung meal and treated tung meal

\begin{tabular}{ccc}
\hline Antinutrients (\%) & Tung meal crude & Tung meal treated \\
\hline Phenolic compounds & $1.23 \pm 0.09$ & $1.41 \pm 0.08$ \\
Total tannins & $1.09 \pm 0.08$ & $1.21 \pm 0.10$ \\
Condensed tannins & $0.025 \pm 0.003$ & $0.018 \pm 0.002^{*}$ \\
Hydrolysable tannins & $1.07 \pm 0.08$ & $1.19 \pm 0.10$ \\
Phytic acid & $1.63 \pm 0.135$ & $0.61 \pm 0.07^{\star}$ \\
In-vitro digestibility of protein & $42.29 \pm 4.25$ & $48.01 \pm 5.98$ \\
\hline
\end{tabular}

Values (\%) expressed as mean \pm standard deviation $(n=3)$ in basis of dry matter. *Indicate difference between treated form and crude form of the meal by $\mathrm{F}$ test $(p<0.05)$.

Within the digestive enzymes, the crude tung meal diet was found to increase the activities of amylase, trypsin and chymotrypsin, reduce the activity of the acid protease and have no effect on the lipase activity compared with the treatment containing treated tung meal at the end of the feeding period. Compared to control diet, fish that consumed either diet containing tung meal had lower lipase activity, and the crude tung meal diet also reduced acid protease activity (Table 5).

Regarding the biochemical parameters, in the plasma of fish fed with the crude tung meal diet, lower glucose, cholesterol and triglycerides levels were observed compared to fish fed with the control diet; however, fish fed with the treated tung meal diet did not differ in any of these parameters compared to fish fed the control diet. The total protein concentrations were similar for all treatment groups evaluated (Table 6). In the hepatic tissue, the animals fed with crude tung meal exhibited reduced glycogen and glucose levels (representing decreased energy reserves), while hepatic protein content was increased compared to the control and treated tung meal diets. The alanine aminotransferase (ALT) concentration was reduced in fish that received the treatment containing treated tung meal, and aspartate aminotransferase (AST) was increased in fish that consumed crude tung meal in their diet (Table 6).

The proximate body composition of silver catfish fed the crude tung meal revealed a higher ash concentration and lower fat percentage when compared with the treated tung meal and control treatments. The dry matter and body protein concentrations were unchanged between treatments (Table 7). 
Table 4. Performance of silver catfish juvenile fed a diet containing crude tung meal or treated tung meal

\begin{tabular}{|c|c|c|c|}
\hline \multirow{2}{*}{ Variables } & \multicolumn{3}{|c|}{ Treatments $^{1}$} \\
\hline & CON & CDT & TTD \\
\hline & \multicolumn{3}{|c|}{ Initial } \\
\hline Live weight (g) & $22.15 \pm 0.24$ & $21.97 \pm 0.36$ & $21.72 \pm 0.35$ \\
\hline \multirow[t]{2}{*}{ Total length $(\mathrm{cm})$} & $13.09 \pm 0.04$ & $13.03 \pm 0.09$ & $13.02 \pm 0.07$ \\
\hline & \multicolumn{3}{|c|}{ Three weeks } \\
\hline Live weight (g) & $34.53 \pm 0.49$ & $21.27 \pm 0.85^{a}$ & $30.31 \pm 0.68^{a^{*}}$ \\
\hline Total length (cm) & $15.27 \pm 0.06$ & $13.39 \pm 0.10^{a}$ & $14.72 \pm 0.16^{a^{*}}$ \\
\hline Specific growth rate (\%/day) & $2.11 \pm 0.02$ & $-0.16 \pm 0.16^{a}$ & $1.59 \pm 0.04^{\mathrm{a}^{*}}$ \\
\hline \multirow[t]{2}{*}{ Feed conversion rate } & $1.13 \pm 0.03$ & - & $1.67 \pm 0.14^{\mathrm{a}}$ \\
\hline & \multicolumn{3}{|c|}{ Six weeks } \\
\hline Live weight (g) & $41.00 \pm 1.84$ & $21.35 \pm 0.54^{a}$ & $35.28 \pm 1.48^{a^{*}}$ \\
\hline Total length (cm) & $16.34 \pm 0.22$ & $13.53 \pm 0.14^{a}$ & $15.54 \pm 0.21^{\mathrm{a}^{*}}$ \\
\hline Specific growth rate (\%/day) & $1.46 \pm 0.10$ & $-0.069 \pm 0.04^{a}$ & $1.15 \pm 0.06^{a^{*}}$ \\
\hline \multirow[t]{2}{*}{ Feed conversion rate } & $3.47 \pm 0.06$ & - & $4.08 \pm 0.78$ \\
\hline & \multicolumn{3}{|c|}{ Nine weeks } \\
\hline Live weight (g) & $52.16 \pm 3.49$ & $21.95 \pm 0.86^{a}$ & $43.69 \pm 2.46^{*}$ \\
\hline Total length $(\mathrm{cm})$ & $17.59 \pm 0.29$ & $13.88 \pm 0.18^{a}$ & $16.59 \pm 0.32^{*}$ \\
\hline Specific growth rate (\%/day) & $1.35 \pm 0.10$ & $-0.0035 \pm 0.06^{a}$ & $1.10 \pm 0.06^{*}$ \\
\hline Feed conversion rate & $2.07 \pm 0.34$ & - & $2.25 \pm 0.25$ \\
\hline Survival (\%) & $98.0 \pm 1.9$ & $68.0 \pm 16.9^{a}$ & $100 \pm 0.0^{*}$ \\
\hline \multicolumn{4}{|c|}{$\begin{array}{l}\text { Values expressed as mean } \pm \text { standard error of mean }(n=3) .{ }^{1} \mathrm{CON}=\text { control diet, with protein base } \\
\text { consisting of animal meal; CTD }=\text { inclusion of crude tung meal in the diet; TTD }=\text { inclusion of treated tung } \\
\text { meal in the diet. Letters indicate difference in CTD or TTD treatments in relation to the control by } \\
\text { Dunnett's test }(p<0.05) \text {. }{ }^{*} \text { Indicate difference between treated form and crude form of the meal by F test } \\
(p<0.05) \text {. }\end{array}$} \\
\hline
\end{tabular}

Table 5. Digestive enzymes activities of silver catfish juvenile fed a diet containing crude tung meal or treated tung meal

\begin{tabular}{|c|c|c|c|}
\hline \multirow{2}{*}{ Variables } & \multicolumn{3}{|c|}{ Treatments $^{1}$} \\
\hline & CON & CTD & TTD \\
\hline Amylase ( $\mu \mathrm{mol}$ glucose/min/mg protein) & $0.33 \pm 0.06$ & $0.43 \pm 0.03$ & $0.21 \pm 0.04^{*}$ \\
\hline Lipase $\left(\mu \mathrm{g}\right.$ substrate/min/mg protein) ${ }^{2}$ & $12.57 \pm 0.69$ & $9.52 \pm 0.56^{a}$ & $9.38 \pm 0.33^{a}$ \\
\hline Acid protease ( $\mu$ g tyrosine/min/mg protein) & $119.9 \pm 7.6$ & $97.1 \pm 6.4^{a}$ & $138.9 \pm 5.1^{*}$ \\
\hline Trypsin ( $\mu \mathrm{mol}$ TAME/min/mg protein) & $8.63 \pm 0.64$ & $9.05 \pm 0.43$ & $7.17 \pm 0.41^{*}$ \\
\hline Chymotrypsin (mmol/BTEE/min/mg protein) & $6.54 \pm 0.41$ & $7.25 \pm 0.49$ & $5.48 \pm 0.19^{*}$ \\
\hline \multicolumn{4}{|c|}{$\begin{array}{l}\text { Values expressed as mean } \pm \text { standard error of mean }(n=6) .{ }^{1} \mathrm{CON}=\text { control diet, with protein base } \\
\text { consisting of animal meal; CTD }=\text { inclusion of crude tung meal in the diet; TTD }=\text { inclusion of treated tung } \\
\text { meal in the diet. }{ }^{2} p \text {-nitrophenyl myristate. Letters indicate difference in CTD or TTD treatments in } \\
\text { relation to the control by Dunnett's test }(p<0.05) \text {. *Indicate difference between treated form and crude } \\
\text { form of the meal by F test }(p<0.05) \text {. }\end{array}$} \\
\hline
\end{tabular}


Table 6. Biochemistry parameters in plasma and liver of silver catfish juvenile fed a diet containing crude tung meal or treated tung meal

\begin{tabular}{lccc}
\hline \multirow{2}{*}{ Variables } & \multicolumn{3}{c}{ Treatments $^{\mathbf{1}}$} \\
\cline { 2 - 4 } & Plasmatic parameters & CTD & TTD \\
\cline { 2 - 4 } & $3.10 \pm 0.07$ & $2.90 \pm 0.12$ & $3.13 \pm 0.09$ \\
\hline Total protein $(\mathrm{g} / \mathrm{dL})$ & $55.9 \pm 3.7$ & $34.1 \pm 2.6^{\mathrm{a}}$ & $47.5 \pm 2.1^{*}$ \\
Glucose $(\mathrm{mg} / \mathrm{dL})$ & $429.6 \pm 56.9$ & $115.3 \pm 20.6^{\mathrm{a}}$ & $237.2 \pm 89.3$ \\
Cholesterol $(\mathrm{mg} / \mathrm{dL})$ & $172.1 \pm 8.1$ & $125.6 \pm 8.1^{\mathrm{a}}$ & $158.4 \pm 17.6$ \\
Triglycerides $(\mathrm{mg} / \mathrm{dL})$ & $446.0 \pm 34.2$ & $93.1 \pm 7.9^{\mathrm{a}}$ & $479.8 \pm 73.2^{*}$ \\
& $379.4 \pm 33.2$ & $156.4 \pm 13.2^{\mathrm{a}}$ & $430.9 \pm 32.8^{*}$ \\
\hline Glycogen $(\mu \mathrm{mol}$ glucose/g) & $49.9 \pm 4.2$ & $73.7 \pm 3.7^{\mathrm{a}}$ & $42.8 \pm 1.9^{*}$ \\
Glucose $(\mu \mathrm{mol}$ glucose/g) & $35.7 \pm 4.4$ & $25.9 \pm 2.2$ & $24.7 \pm 1.7^{\mathrm{a}}$ \\
Protein $(\mathrm{mg} / \mathrm{g})$ & $687.9 \pm 107.2$ & $838.8 \pm 50.8$ & $691.8 \pm 25.5^{*}$ \\
ALT $(\mathrm{Ul} / \mathrm{mg})$ & & &
\end{tabular}

Values expressed as mean \pm standard error of mean $(n=6)$. ${ }^{1} \mathrm{CON}=$ control diet, with protein base consisting of animal meal; CTD = inclusion of crude tung meal in the diet; TTD = inclusion of treated tung meal in the diet. Letters indicate difference in CTD or TTD treatments in relation to the control by Dunnett test $(p<0.05)$. *Indicate difference between treated form and crude form of the meal by $F$ test $(p<0.05)$.

Table 7. Initial body composition of silver catfish juvenile and after feeding with diet containing crude tung meal or treated tung meal

\begin{tabular}{ccccc}
\hline & \multicolumn{4}{c}{ Nutrients (\%) } \\
\cline { 2 - 5 } Treatments $^{1}$ & Dry matter & Ash & Crude protein & Fat \\
\hline Initial & $25.69 \pm 0.27$ & $3.34 \pm 0.16$ & $14.30 \pm 0.26$ & $8.20 \pm 0.40$ \\
\cline { 2 - 5 } Nine weeks & & & & \\
CON & $26.17 \pm 0.76$ & $3.05 \pm 0.10$ & $15.47 \pm 0.10$ & $9.05 \pm 0.57$ \\
CTD & $26.85 \pm 0.60$ & $3.65 \pm 0.18^{\mathrm{a}}$ & $15.91 \pm 0.55$ & $6.76 \pm 0.31^{\mathrm{a}}$ \\
TTD & $28.57 \pm 0.87$ & $3.14 \pm 0.13^{*}$ & $15.59 \pm 0.34$ & $11.14 \pm 0.77^{*}$ \\
\hline
\end{tabular}

Values expressed as mean \pm standard error of mean $(n=6) .{ }^{1} \mathrm{CON}=$ control diet, with protein base consisting of animal meal; CTD = inclusion of crude tung meal in the diet; TTD = inclusion of treated tung meal in the diet. Letters indicate difference in CTD or TTD treatments in relation to the control by Dunnett's test $(p<0.05)$. ${ }^{*}$ Indicate difference between treated form and crude form of the meal by F test $(p<0.05)$.

\section{Discussion}

The chemical treatment, based on the use of acidic and alcoholic solutions, allowed the removal of the condensed tannins and phytic acid present in the tung meal. The removal of these anti-nutritional factors occurs when the fractions are solubilised in the relevant solvents like ethanol, methanol, acetone or water. The solubility of the phenolic compounds depend on the kind of solvent used, the degree of polymerisation of phenols and interactions with the other components of the feed ${ }^{(28)}$. The application of 
chemical treatment did not reduce antinutrients such as phenols and tannins (total and hydrolysable) in tung meal, possibly due to the insolubility of these molecules, as well as the increase of neutral detergent fibre in the meal, because the higher concentration of these compounds is usually present in the fibrous fractions as shells and pericarp ${ }^{(29)}$. For the removal of phenolic compounds from canola, ethanolic extraction, with 95\% ethanol for 30 minutes, was the most efficient method compared to extraction with water at temperatures of either 160,110 or $80^{\circ} \mathrm{C}$ over a 30 minute period ${ }^{(30)}$. The main treatment for the extraction of phytic acid in the seeds and plants of sharps is achieved by treatment with enzymes or acids ${ }^{(6)}$. For soybean meal, $1 \mathrm{~N}$ hydrochloric acid more effectively removed phytic acid (87\% extraction) compared to either sulphuric, phosphoric or formic acids ${ }^{(31)}$. For rice, a $5 \%$ sulphuric acid solution has previously been shown to remove the highest amount of phytic acid compared to $10 \%$ trichloroacetic acid and $3 \%$ hydrochloric acid(32).

The removal of antinutrients from plant meals improves the ability to use these ingredients in fish diets, as several studies have reported that the addition of such ingredients at specific concentrations reduce the growth performance of fish. For example, the inclusion of crude canola meal in the diets of Lateolabrax japonicus (sea bass) was shown to reduce growth, feed efficiency, digestive enzyme activities and survival, demonstrating that protein replacement with crude canola meal should not exceed $20 \%{ }^{(33)}$. Fish fed with diets containing either replacement with soybean or sunflower meals had higher weight gain, feed conversion rate and protein efficiency compared to those fed with canola or cottonseed meals ${ }^{(34)}$. The observed difference can be attributed to the high levels of complex carbohydrates and crude fibre in the canola and cottonseed meals, in addition to their unbalanced essential amino acid profile.

Another study investigated the inactivation of trypsin inhibitors and lectins and the removal of phorbol esters in Jatropha curcas, another species of the Euphorbiaceae family, to which tung belongs ${ }^{(35)}$. In that study, the solvent and heat treatments were applied for shorter (30 minutes) or longer (60 minutes) periods. The meal detoxified for the shorter time (30 minutes) resulted in reduced weight gain, specific growth rate and body weight of animals. In addition, this meal had decreased digestibility of proteins and other nutrients. The poor performance was attributed to the incomplete detoxification of the meal. In contrast, the J. curcas meal detoxified for the longer time period (60 minutes) had a lower antinutrient concentration. When this was included in the feed provided to Cyprinus carpio (carp) fingerlings, it resulted in a growth response similar to that of the control diet, which contained fish and wheat meal as the protein sources. Similarly, in our study, the poor performance and increased mortality observed in fish fed the diet containing crude tung meal are most likely to be associated with the presence of anti-nutritional factors. These substances can be released in the fish intestines during digestion, resulting in an impaired growth response and pathological lesions in organs or mucous cells ${ }^{(36)}$. The chemical treatment may have also removed other antinutritional factors in addition to phytic acid and condensed tannins, potentially even toxic substances, which may have contributed to the better performance of the animals that consumed treated tung meal. Similar to the results observed with silver catfish, treated tung meal also promoted greater growth of $C$. carpio juveniles compared to 


\section{crude tung meal ${ }^{(7)}$.}

The response of digestive enzymes to dietary changes observed in nutrition studies aids our understanding of fish growth. The activity level and profile of digestive enzymes may vary based on the type, source and amount of nutrients in the $\operatorname{diet}^{(37)}$. Most studies have shown that the antinutrients present in plant feedstuffs reduces the activity of digestive enzymes ${ }^{(36,38)}$. For example, an in vitro study showed lower protease, amylase and lipase activities in the intestinal homogenates of Labeo rohita (rohu) as a result of the addition of tannins to the diet at various concentrations, $6.25-200 \mu g^{(39)}$. These enzymes also showed reduced activity when J. curcas meal was fed to carp, due the presence of phytic acid(35). However, Rodiles et al.(40) observed an increase in total protease, trypsin and chymotrypsin activities in Solea senegalensis (sole) juveniles when they were fed soybean meal, soybean protein isolate, wheat gluten meal or pea protein isolate as partial substitutes for fish meal. These changes in the distribution and activity of digestive enzymes have been identified as a compensatory mechanism in the digestion process, and this may be an adaptive physiological response by the fish to the poor quality of plant meal and/or the presence of antinutritional factors ${ }^{(40)}$. In this study, although we observed an increase in the digestive enzyme activity amylase, trypsin and chymotrypsin, animals fed crude tung meal also presented reduced growth and increased mortality compared to the fish that received the treated tung meal, possibly due to higher levels of antinutrients.

The blood is a dynamic tissue in the body as it is able to quickly reflect changes in physiology, nutrition and health, and can also be used to indicate a stress response ${ }^{(41)}$. A reduction in energy precursors in the post-prandial period, such as glucose, triglycerides and even proteins, reflects low feed intake combined with low nutrient digestibility and absorption, which can lead to an energy deficit in an organism. In the silver catfish juveniles fed crude tung meal, the changes observed in the basal values of glucose and other energy precursors, like triglycerides and cholesterol in the blood, are related to changes in energy reserves, including glycogen in liver and muscle and triglycerides in the adipose tissue. If these energy stocks are not replenished after every meal, the energy available for maintenance processes in the body is reduced, which can interfere with the growth of the fish.

Some studies have associated the animal growth responses to a specific diet to metabolic changes that appear in organs such as the liver, via the measurement of parameters related to protein and energy metabolism. These parameters can be used to indicate optimum nutrient usage, as the liver receives and distributes nutrients from the digestive process. The alanine aminotransferase and aspartate aminotransferase enzymes evaluated in this study are involved in the process of obtaining energy from amino acids. An increase in the concentration of these enzymes can indicate inefficient protein utilisation, which is undesirable. Fournier et al.(42) also observed increased alanine aminotransferase and aspartate aminotransferase activity when fish meal was replaced by lupin, wheat gluten and corn gluten meal in the diet of Psetta maxima (turbot). In our study, fish fed with crude tung meal had increased aspartate aminotransferase activity compared to those fed with the treated tung meal. The increase in aspartate 
aminotransferase concentration was related to reduced concentrations of glycogen and glucose, the major energy reserves. In this situation, the organism adopts a metabolic strategy to increase gluconeogenesis in order to obtain enough energy to maintain blood glucose levels and replenish glycogen storage, mainly using amino acids as a substrate, which releases ammonia and increases transaminase activity. Therefore, amino acids are diverted from their primary function in tissue formation and used in the acquisition of energy. High concentrations of the aspartate aminotransferase enzyme may indicate increased liver protein levels. Therefore, the digestive and metabolic changes observed in fish fed crude tung meal were reflected in the growth response of the animals. However, the incorporation of chemically treated tung meal into the silver catfish feed resulted in a similar growth rate compared to fish fed the control diet, and only mild metabolic changes were observed, suggesting that the nutritional value of the meal was improved after the chemical treatment.

In relation to nutrient deposition in the body, the higher ash concentration observed in animals fed with crude tung meal diet may have resulted from their body nutrient concentration, due to the growth stagnation observed in fish in this treatment group. These fish also exhibited a decrease in whole body fat content, which, along with the decrease in plasma triglyceride concentration, may suggest significant lipid mobilisation in this group. Similar results were found in turbot that consumed diets which were supplemented with more than $20 \%$ corn gluten meal(43). Moisture and fat usually vary inversely in the flesh of fish. This was observed in the fish that received the treated tung meal diet, which had higher body fat and 9\% more dry matter in the carcasses compared to those fed the crude tung meal diet, and was not significantly different from the control treatment. A similar result was observed by Elangovan \& Shim ${ }^{(44)}$ and Kaushik et al.(45), where animal meal was replaced with vegetable meal. In these studies, body protein concentration did not differ among treatments compared to control because protein concentration is less variable. This is a significant result in relation to nutrition and fish farming.

\section{Conclusion}

Inclusion of chemically treated tung meal at 32\% in fish feed resulted in significantly higher growth compared with diets including crude meal, emphasising the importance of removing antinutrients from the meal. The tung meal obtained after chemical treatment can partially replace animal meal in the diet of silver catfish juveniles; however, future studies will be required to determine the maximum inclusion concentration of meal in the diet.

\section{Acknowledgments}

Financial support: Conselho Nacional de Desenvolvimento Científico e Tecnológico (CNPq), Fundação de Amparo à Pesquisa do Rio Grande do Sul (FAPERGS). To Indústria 
Effect of feeding crude or treated tung meal (Aleurites fordii) in the diet of Rhamdia quelen on growth

Pretto, A. et al.

\section{de Óleos Varela (RS) for donating the vegetable meal (tung).}

\section{References}

1 IBGE - Instituto Brasileiro de Geografia e Estatística. Produção Agrícola Municipal 2015. Acesso em 16 de janeiro de 2017. Disponível em: http://cidades.ibge.gov.br/comparamun /compara.php?lang=\&coduf=4 3\&idtema=157\&codv=v161\&search=rio-grande-do-sul| bento-goncalves / sintese-das-informacoes-2015

2 dos Anjos e Silva S D, de Ávila D T, Aires R F, de Ávila T T. Desempenho agronômico de plantios comerciais de tungue no Rio Grande do Sul. Empresa Brasileira de Pesquisa Agropecuária. Boletim de Pesquisa e Desenvolvimento, n. 186, 2013. Disponível em: https://www.infoteca.cnptia.embrapa.br/ bitstream/ doc/992696/1/Boletim186web.pdf Português

3 Hardy R. Utilization of plant in fish diets: effects of global demand and supplies of fishmeal. Aquaculture Research, 2010; 41(5):770-776. Disponível em: http://onlinelibrary.wiley.com/doi/10.11 11/j.13652109.2009.02349.x/epdf

4 Francis G, Makkar H P S, Becker K. Antinutritional factors present in plant-derived alternate fish feed ingredients and their effects in fish. Aquaculture, 2001; 199(3-4:197-227. Disponível em: http://ac.elscdn.com/S0044848601005269/1-s2.0-S0044848601005269-main.pdf? tid=ade1517e-f8f1 -11e6-ae0600000aacb361\&acdnat=1487762937_05aa894ea37117527d1 b01f87243ed 20

5 Mann G E, Hoffman W H, Ambrose A M. Detoxification and toxicological studies of tung meal. Journal of Agricultural and Food Chemistry, 1954; 2:258-263.

6 Kumar V, Sinha A K, Makkar H PS, De Boeck G, Becker K. Phytate and phytase in fish nutrition. Journal of Animal Physiology and Animal Nutrition, 2012; 96(3):335-364. Disponível em: http://onli nelibrary.wiley. com/doi/10.1111/j.1439-0396.2011.01169.x/epdf

7 Pretto A, Silva L P, Goulart F R, Battisti E K, Loureiro B B, Eggers D P, Pianesso D. Farelo de tungue in natura ou detoxificado na alimentação de carpa húngara (Cyprinus carpio). Arquivo Brasileiro de Medicina Veterinária e Zootecnia, 2014; 66(6):1891-1900. Disponível em: http://www.scielo.br/pdf/ abmvz/v66n6/0102-0935-abmvz-66-06-01891.pdf Português

8 Makkar H P S. Quantification of Tannins in Tree Foliage. 2000. Acesso em 10 de janeiro de 2017. Disponível em: http://central-lab.tabrizu.ac.ir/Files/manual-tannin\%2001.pdf.

9 Latta M, Eskin M. A simple and rapid colorimetric method for phytate determination. Journal of Agricultural and Food Chemistry, 1980; 28:1313-1315.

10 Dias D R, Abreu C M P, Silvestre M P, Schwan R F. In vitro protein digestibility of enzymatically pre-treated bean (Phaseolus vulgaris L.) flour using commercial protease and Bacillus sp. protease. Food Science and Technology, 2010; 30(1):94-99. Disponível em: http://www.scielo.br/pdf/cta/v30n 1/aop_3218.pdf

11 Association of Official Analytical Chemists. Official Methods of Analysis, $16^{\mathrm{a}}$ ed. Washington: Association of Official Analytical Chemists. 1995. 1137p.

12 Bligh E G, Dyer W J. A rapid method of total lipid extraction and purification. Canadian Journal of Biochemistry and Physiology, 1959; 37(8):911-917. Disponível em: http://www.nrcresearchpress.com / doi/pdf/10.1139/059-099

13 Van Soest P J, Robertson J B, Lewis B A. Symposium: carbohydrate methodology, metabolism, and nutritional implications in dairy cattle. Journal of Dairy Science, 1991; 74:3583-3597. Disponível em: http://webpages.icav.up.pt/ptdc/CVT/098487/2008/Van\%20Soest,\%201991.pdf

14 Baginski E S, Slawa S M, Zak B. Phosphate, inorganic. In Baginski E S. Selected Methods of Clinical 
Effect of feeding crude or treated tung meal (Aleurites fordii) in the diet of Rhamdia quelen on growth Pretto, A. et al.

Chemistry. Washington: American Association Clinic Chemistry; 1982. p. 313-316

15 Montes-Girao P J, Fracalossi D M. Dietary lysine requirement as basis to estimate the essential dietary amino acid profile for jundiá, Rhamdia quelen. Journal of the World Aquaculture Society, 2006; 37(4):388396. Disponível em: http://onlinelibrary.wiley.com/doi/10.1111/j.1749-7345.2006.00 052.x/epdf

16 Meyer G, Fracalossi D M, Borba M R. A importância da quantidade de energia na ração de peixes. Panorama da Aquicultura, 2004; 14:53-57. Disponível em: http://www.panoramadaaquicultura.com. br/ paginas/revistas/83/energia83.asp Português

17 Verdouw H, Vanechteld C J A, Deckkers E M J. Ammonia determinations based on indophenol formation with sodium salicylate. Water Research, 1978; 12(6):399-402. Disponível em: http://ac.els-cdn. com/0043135478901070/1-s2.0-0043135478901070-main.pdf? tid=b960836a-f8f3-11e6-bd08-00000aa b0f27\&acdnat $=1487763815$ 2d8acf1cc17106157e2fb8ab96625132

18 Boyd C E, Tucker C S. Water quality and pond soil analysis for aquaculture. Alabama: Alabama Agricultural Experiment Station, Auburn University; 1992. 183p.

19 Baldisserotto B, Silva L V F. Qualidade da água. In Baldisserotto B, Radünz Neto J. Criação do jundiá. Santa Maria: Editora da UFSM; 2004. p. 73-92.

20 Cunha M A, Zeppenfeld C C, Garcia L O, Loro V L, Fonseca M B, Emanuelli T, Veeck A P L, Copatti C $\mathrm{E}$, Baldisserotto B. Anesthesia of silver catfish with eugenol: time of induction, cortisol response and sensory analysis of fillet. Ciência Rural, 2010; 40(10):2107-2114. Disponível em: http://www.scielo.br/pdf/ cr/v40n10/a722cr3388.pdf

21 Hidalgo M C, Urea E, Sanz A. Comparative study of digestive enzymes in fish with different nutritional habits. Proteolytic and amylase activities. Aquaculture, 1999; 170(3-4):267-283. Disponível em: http:// ac.els-cdn.com/S004484869800413X/1-s2.0-S004484869800413X-main.pdf? tid=03ea30b6-f8f4-11e68d62-00000aab0f6b\&acdnat=1487763940d287aef9656e9da19374d853b80a 463d

22 Hummel B C W. A modified spectrophotometric determination of chymotrypsin, trypsin and thrombin. Canadian Journal of Biochemistry and Physiology, 1959; 37:1393-1399.

23 Park JT, Johnson M J. A submicro determination of glucose. Journal of Biological Chemistry, 1949; 181:149-151. Disponível em: http://www.jbc.org/content/181/1/149.long

24 Gawlicka A, Parent B, Horn M H, Ross N, Opstad I, Torrissen O J. Activity of digestive enzymes in yolk-sac larvae of Atlantic halibut (Hippoglossus hippog/ossus): indication of readiness for first feeding. Aquaculture, 2000; 184(3-4):303-314. Disponível em: http://ac.els-cdn.com/S004484869900 3221/1-s2.0-S0044848699003221-main.pdf? tid=7dbce91a-f8f4-11e6-8435-00000aacb35d\&acdnat= 1487764144_3594a7efdbeebdebb9dfcbbf6250f50e

25 Bradford M M A. A rapid and sensitive method for the quantification of microgram quantities of protein utilizing the principle of protein-dye binding. Analytical Biochemistry, 1976; 72(1-2):248-254. Disponível em: http://ac.els-cdn.com/0003269776905273/1-s2.0-0003269776905273-main.pdf?tid=9 9ee3486-f8f411e6-8b5f-00000aacb35f\&acdnat=1487764192_2ff941d898dbbee8b1a1e252654098d5

26 Bidinotto P M, Moraes G, Souza R H S. Hepatic glycogen and glucose in eight tropical freshwater teleost fish: A procedure for field determinations of micro samples. Boletim Técnico do CEPTA, 1997; 10:53-60. Disponível em: http://www.icmbio.gov.br/cepta/images/stories/producaocientifica/he patic199701.pdf.

27 Dubois M G, Gilles K A, Hamilton J K, Roberts P A, Smith F. Colorimetric method for determination of sugars and related substances. Analytical Chemistry, 1956; 28:350-358.

28 Naczk M, Shahidi F. Extraction and analysis of phenolics in food. Journal of Chromatography A, 2004; 1054(1-2):95-111. Disponível em: http://ac.els-cdn.com/S0021967304014098/1-s2.0-S0021967 304014098-main.pdf? tid=d68f7756-f8f4-11e6-a7b0-00000aacb362\&acdnat=1487764293 6fdfec3c9 
Effect of feeding crude or treated tung meal (Aleurites fordii) in the diet of Rhamdia quelen on growth

Pretto, A. et al.

\section{ebe7888abeb7f1bf54da26e}

29 Silva M R, Silva M A A P. Aspectos nutricionais de fitatos e taninos. Revista de Nutrição, 1999; 12(1): 5-19. Disponível em: http://www.scielo.br/pdf/rn/v12n1/v12n1a02.pdf

30 Hassas-Roudsari M, Chang P R, Pegg R B, Tyler R T. Antioxidant capacity of bioactives extracted from canola meal by subcritical water, ethanolic and hot water extraction. Food Chemistry, 2009; 114(2):717-726. Disponível em: http://ac.els-cdn.com/S0308814608011928/1-s2.0-S03088146080119 28-main.pdf? tid=1 ee2fdfc-f8f5-11e6-8367-00000aacb360\&acdnat=1487764415 17d7c725f3a0050c 3bdc837ada859b63

31 Han Y W. Removal of phytic acid from soybean and cottonseed meals. Journal of Agricultural and Food Chemistry, 1988; 36:1181-1183.

32 Saad N, Esa N M, Ithnin H, Shafie N M. Optimization of optimum condition for phytic acid extraction from rice bran. African Journal of Plant Science, 2011; 5(3):168-176. Disponível em: http://www. academicjournals.org/article/article1379945219_Saad\%20et\%20al.pdf

33 Cheng Z, Ai Q, Mai K, Xu W, Ma H, Li Y, Zhang J. Effects of dietary canola meal on growth performance, digestion and metabolism of Japanese seabass, Lateolabrax japonicus. Aquaculture, 2010; 305(1-4):102-108. Disponível em: http://ac.els-cdn.com/S0044848610002036/1-s2.0s0044848610002036-main.pdf? tid=85d06c98-f8f5-11e6-8a58-00000aacb362\&acdnat $=1487764587$ 106613e4be9f293c940d89085ebb9c89

34 Bilgüven $M$, Baris $M$. Effects of the feeds containing different plant protein sources on growth performance and body composition of rainbow trout (Oncorhynchus mykiss, W.). Turkish Journal of Fisheries and Aquatic Sciences, 2011; 11:345-350. Disponível em: http://www.trjfas.org/uploads/pdf 581. pdf

35 Kumar V, Makkar H P S, Becker K. Detoxified Jatropha curcas kernel meal as a dietary protein source: growth performance, nutrient utilization and digestive enzymes in common carp (Cyprinus carpio L.) fingerlings. Aquaculture Nutrition, 2011; 17(3):313-326. Disponível em: http://onlinelibrary .wiley.com/ doi/10.1111/j.1365-2095.2010.00777.x/epdf

36 Kumar V, Makkar H P S, Amselgruber W, Becker K. Physiological, haematological and histopatological responses in common carp (Cyprinus carpio L.) fingerlings fed with differently detoxified Jatropha curcas kernel meal. Food and Chemical Toxicology, 2010; 48(8-9):2063-2072. Disponível em: http://ac.elscdn.com/S0278691510002826/1-s2.0-S0278691510002826-main.pdf?tid =f3e9f60e-f8f5-11e6-93a900000aab0f01\&acdnat $=1487764772$ ff3500a5a7e6f0618b8afc50589b27bc

37 Lundstedt LM, Melo J F B, Moraes G. Digestive enzymes and metabolic profile of Pseudoplatystoma corruscans (Teleostei: Siluriformes) in response to diet composition. Comparative Biochemistry and Physiology PartB, 2004; 137(3):331-339. Disponível em: http://ac.els-cdn.com/S1 096495903003828/1-s2.0S1096495903003828-main.pdf? tid=a6295a44-f8f6-11e6-935b-00000aab0 f27\&acdnat $=1487765071$ a1cb194c9a4433f126efbc9e9fe5a295

38 Lin S, Luo L. Effects of different levels of soybean meal inclusion in replacement for fish meal on growth, digestive enzymes and transaminase activities in practical diets for juvenile tilapia, Oreochromis niloticus x O. aureus. Animal Feed Science and Technology, 2011; 168(1-2):80-87. Disponível em: http:// ac.els-cdn.com/S0377840111001118/1-s2.0-S0377840111001118-main.pdf?tid =d37ab0ba-f8f6-11e69437-00000aab0f27\&acdnat=1487765147c4f24767df7108abdae4b2b0ac2b607 7

39 Maytra S, Ray A K. Inhibition of digestive enzymes in rohu, Labeo rohita (Hamilton), fingerlings by tannin: an in vitro study. Aquaculture Research, 2003; 34(1):93-95. Disponível em: http://onlinelib rary. wiley.com/doi/10.1046/j.1365-2109.2003.00792.x/epdf

40 Rodiles A, Santigosa E, Herrera M, Hachero-Cruzado I, Cordero M L, Martínez-Llorens I, Lall S P, Alarcón FJ. Effect of dietary protein level and source on digestive proteolytic enzyme activity in juvenile Senegalese 
Effect of feeding crude or treated tung meal (Aleurites fordii) in the diet of Rhamdia quelen on growth

Pretto, A. et al.

sole, Solea senegalensis Kaup 1850. Aquaculture International, 2012; 20(6):1053-1070. Disponível em: $\quad$ http://download.springer.com/static/pdf/175/art\%253A10.1007\%252Fs10499-012-9508-6. pdf?originUrl=http\%3A\%2F\%2Flink.springer.com\%2Farticle\%2F10.1007\%2Fs10499-01 2-9508-6\&token2=exp=1487766305 acl=\%2Fstatic\%2Fpdf\%2F175\%2Fart\%25253A10.1007\%2525 2Fs10499-012-9508-6.pdf\%3ForiginUrl\%3Dhttp\%253A\%252F\%252Flink.springer.com\%252Farti cle\%252F10.1007\%252Fs10499-012-9508-6* hmac=878f9c64f722d8add3e535e07b8d4268d6eb1 de2964bb300afb1ecbe325a266

41 Kader Md A, Bulbul M, Koshio S, Ishikawa M, Yokoyama S, Nguyen B T, Komilus C F. Effect of complete replacement of fishmeal by dehulled soybean meal with crude attractants supplementation in diets for red sea bream, Pagrus major. Aquaculture, 2012; 350-353:109-116. Disponível em: http://ac.elscdn.com/S004484861200213X/1-s2.0-S004484861200213X-main.pdf? tid=52cee048-f8 f7-11e6-8da000000aab0f6c\&acdnat=1487765361 fa6a2f31acb112317f430b09d538a597

42 Fournier V, Huelvan C, Desbruyeres E. Incorporation of a mixture of plant feedstuffs as substitute for fish meal in diets of juvenile turbot (Psetta maxima). Aquaculture, 2004; 236(1-4):451-465. Disponível em: http://ac.els-cdn.com/S004484860400081X/1-s2.0-S004484860400081X-main.pdf? tid=70e6539a-f8f711e6-ba97-00000aab0f26\&acdnat=1487765411_6d7897869fcbaae77dbd49bbad 2ece40

43 Regost C, Arzel J, Kaushik S J. Partial or total replacement of fish meal by corn gluten meal in diet for turbot (Psetta maxima). Aquaculture, 1999; 180(1-2):99-117. Disponível em: http://ac.els-cdn. com/S0044848699000265/1-s2.0-S0044848699000265-main.pdf?_tid=8c74ada0-f8f7-11e6-867a-000 00aab0f6c\&acdnat=1487765457_2e466335879af0a39f99a638f2dd8f9 $\bar{d}$

44 Elangovan A, Shim K F. The influence of replacing fish meal partially in the diet with soybean meal on growth and body composition of juvenile tin foil barb (Barbodes altus). Aquaculture, 2000; 189(12):133-144. Disponível em: http://ac.els-cdn.com/S0044848600003653/1-s2.0-S004484860000 3653main.pdf? tid=a8c8defe-f8f7-11e6-819c-00000aacb35e\&acdnat $=14877655056 f 1$ e $8788090467 \mathrm{e}$ aaba2e5e93c335b45

45 Kaushik SJ, Covès D, Dutto G, Blanc D. Almost total replacement of fish meal y plant protein sources in the diet of a marine teleost, the European seabass, Dicentrarchus labrax. Aquaculture, 2004; 230:391-404. Disponível em: http://webpages.icav.up.pt/ptdc/CVT-NUT/4294/2012/Kaushick \%202004.pdf 